\title{
Study of Some New Entolomes Species for Fungal Flora of Morocco
}

\author{
Ahmed Ouabbou, Saifeddine El Kholfy, Anas Nmichi, Amina Ouazzani Touhami, \\ Rachid Benkirane, Allal Douira
}

Université Ibn Tofail, Faculté des Sciences, Laboratoire de Botanique, Biotechnologie et de Protection des Plantes, B.P. 133, Kenitra, Marocco

\begin{abstract}
In this study, four species of Entolomataceae family, were studied namely Entoloma papillatum, Entoloma rhodopolium, Nolanea hirtipes and N. cucullata are harvested for the first time in Morocco. The genus Entoloma' species were encountered in Quercus suber in the forest of Mamora (Northwestern Morocco) and those of the Nolanea' genus under Quercus rotundifolia in the forest El Harcha (Northeast of the Central Plateau).
\end{abstract}

Keywords - Entolomataceae, Entoloma, Nolanea, Mamora, Morocco.

\section{INTRODUCTION}

The genera Entoloma (Fr. ex Rabenh.) P. Kumm., (1871) and Nolanea (Fr.) P. Kumm., (1871), belong to the Entolomataceae' family (Order of Agaricales, Subclass Agaricomycetidae, Class of Agaricomycetes, Sub Division of Agaricomycotina, Division of Basidiomycota, Kingdom of Fungi) (Kirk et al., 2008).

Most of entolome species of Entolomataceae are saprophytes; they develop on organic debris such as twigs, dead leaves and the corpses. However, there also exist lignivores species that live in symbiosis with different autotrophic plants (Perraudin, 2002), case of Entoloma lividoalbum (Kühner \& Romagn.) M. M. Moser., (1978), Entoloma nidorosum (Fr.) Quél., (1872), (= Entoloma rhodopolium (Fr.) P. Kumm., 1871) and Entoloma politum (Pers.) Donk, (1979) which are ectomycorrhizal fungi (Nounsi et al., 2014).

The entolome are characterized by a silhouette type of pleurotoïde, omphaloïde, collybioïde, mycenoïde ou tricholomatoïde and fibrillose cap, squamulose and rough. Due to the great heterogeneity silhouettes of entolomes, the microscopic characters are fundamentals to determine the different species (Noordeloos, 1992).

Entoloma is the second biggest genera of the Agaricales. It is monophyletic and presents highly variable morphological characters (Co-David et al., 2009). This genera represented by 1500 species, is well distributed all over the world, from the Arctic to tropical habitats (Romagnesi \& Gilles, (1979) ; Horak (1980, 2008) ; Noordeloos, (1981, 1992, 2004) ; Largent, (1994) ;
Manimohan et al., (2006); Gates \& Noordeloos, (2007, 2009); Noordeloos \& Hausknecht, (2007)). The genus Entoloma is characterized by pink spores, angular and polygonal. These spores' forms are considered as important elements in determining the entolomes (Noordeloos, (1992); Manimohan et al., (2006); Gates \& Noordeloos, (2007); Horak, (2008) and Noordeloos \& Gates (2009)).

Fries (1821) erected Nolanea as a "tribe" of Agaricus due to their pink spores. Whereas other authors have considered, according to microscopic characters as a genera (Dennis, (1953, 1970); Pegler, (1983, 1997); Largent \& Baroni, (1988) and Largent, (1994)) or sub genera (Noordeloos (1981, 1992 and 2004)).

The species of the Nolanea'genus are cosmopolitans and easily recognized as species belonging to the family of Entolomataceae (Agaricales) owing to their angular and pink basidiospores (Henkel et al., 2014). They are mainly saprotrophic (Largent, 1994) and have a conical to convex cap, adnate lamina (they can be a little decurrent) and a fragile and often hollow stipe (Dennis, (1953, 1970); Pegler, (1983, 1997) and Largent, (1994)).

In this work, four species of Entoloma and Nolanea' genera have been studied namely Entoloma papillatum, Nolanea hirtipes and N. cucullata collected for the first time in Morocco.

\section{MATERIALS AND METHODS}

Prospecting, carried out from winter to spring between 2010 and 2012, in the cork oak forest of Mamora (northwestern Morocco) and El Harcha forest (northeast of the central plateau) allowed us to encounter species of the genera Entoloma (Fr. ex Rabenh.) P. Kumm., (1871) and Nolanea (Fr.) P. Kumm., (1871). The specimens of these species were collected and brought back to the laboratory. Microscopic descriptions of carpophores focused on the morphological characters (shape, color, size, appearance...) well as other particularities of the cap and stipe (odor, taste ...). This description is completed by a microscopic description of spores and cuts at the hymenium, the cuticle, flesh and stipe. The dimensions of spores, cystidia, 
basidia and sometimes sterigmata are measured via a micrometer wide-field eyepiece $10 \times(18 \mathrm{~mm})$ at scale 10 $\mathrm{mm}$ divided into 100 graduations $(0.1 \mathrm{~mm})$. The microscopic observations have been conducted using an optical microscope (magnification $\times 400$ ). The mounting liquid is tap water. The shape of the spores is obtained by calculating the quotient of the Bas (1969) according to the following ratio, $\mathrm{Q}=$ length $(\mathrm{L}) /$ width (1).

Species identification was conducted by consulting the work of Kirk et al., (2008); Roux, (2006); Courtecuisse \& Duhem, (2000); Noordeloos, (1981, 1992 and 2004); Roger, (1981) and Malençon \& Bertault, (1970).

\section{RESULTS}

The species Entoloma papillatum and E. rhodopolium were collected under Quercus suber in Mamora forest while Nolanea hirtipes and N. cucullata were collected under Quercus rotundifolia in the forest El Harcha (Northeast of the Central Plateau).

\section{Entoloma papillatum (Bres.) Dennis, (1953)}

Humicolous species collected under the Quercus suber on february 13, 2010 in the Mamora forest.

The cap (5 cm diameter) is circular, plano convex, smooth, hilly and beige-brown to brown in the center. The flesh is more or less thin and whitish. The margin is simple and straight. The stipe $(2 \times 0.2 \mathrm{~cm})$ is cylindrical, central, fibrillose, hollow and pale beige. The blades are adnate, tight, potbellied, uneven and pinkish color. Involves edge breaking is toothed and regular.

The basidia (39.9 $\mu \mathrm{m}$ in length and $11.65 \mu \mathrm{m}$ in width) hyaline, clavate, tetrasporic with sterigmata of $3.9 \mu \mathrm{m}$. The cheilocystidia $(33.3 \mu \mathrm{m}$ in length and $9.99 \mu \mathrm{m}$ in width) are hyaline, clavate rounded apex and thick wall. The basidiospores (from 7.3 to $9.3 \mu \mathrm{m}$ in length and from 6.6 to $8.3 \mu \mathrm{m}$ in width) are globular, angular and more or less thick wall.

\section{Entoloma rhodopolium (Fr.) P. Kumm., (1871).}

Humicolous species collected on February 05, 2011 and December 21, 2012 under Quercus suber in the Mamora forest.

The cap (6.5 cm diameter) is circular, plano convex, smooth, flared and olive-gray color. The flesh, whitish, spongy, thick in the center and thinner towards the margins. The margin is smooth and curved. The stipe, whitish, is potbellied on top $(7 \times 0.75 \mathrm{~cm})$, mitigated at the base $(0.5 \mathrm{~cm}$ wide), central hollow, fistulous, spongy and fibrillose. The blades are emarginate, closely spaced, broad, uneven and greyish-white at pinkish reflection. Involves edge breaking is toothed.

The basidia (36.6 $\mu \mathrm{m}$ in length and $8.32 \mu \mathrm{m}$ in width) are hyaline, clavate, tetrasporic with sterigmata of $2,3 \mu \mathrm{m}$.
Basidiospores (7.3 $\mu \mathrm{m}$ in length and $6.6 \mu \mathrm{m}$ in width) are globose, angular and more or less thick wall.

Nolanea hirtipes (Schum. ex Fr.) Kummer, (1871).

Humicolous species collected on December 13, 2010 under Quercus rotundifolia in El Harcha forest.

The cap ( $2 \mathrm{~cm}$ diameter) is circular, convex and smooth, with a small nipple in the center, gray and beige. The flesh is thin and beige. The margin is ridged and more or less curved. The stipe $(4-5 \times 0.25 \mathrm{~cm})$ is cylindrical, small, central, fibrillose, hollow, smooth and grayish in color. The blades are adnate, tightened, unequal, triangular and brownish gray color. Involves edge breaking is smooth and whitish.

The basidia $(43.3 \times 10 \mu \mathrm{m})$ are tetrasporic, hyaline and clavate. The sterigmata are of $6 \mu \mathrm{m}$. Basidiospores (from 6.6 to $9.9 \times 6.6$ to $8.3 \mu \mathrm{m}$ ) are globular, angular and with very visible germinal pore.

Nolanea cucullata (J. Favre, 1955) P.D. Orton, 1960

Humicolous species collected on December 20, 2012 under Quercus rotundifolia in the El Harcha forest.

The cap (1-1.5 cm in diameter) is circular, conical to plano convex, smooth and has a small nipple and dark gray color. The flesh is thin and gray. The margin is ridged, rolled up and black. The stipe $(2 \times 0.1 \mathrm{~cm})$ is cylindrical, central, small, fibrillose, full fistulous and blackish gray color. The blades are free, closely spaced, potbellied, unequal and creamy color white with pinkish reflection. Involves edge breaking is smooth and whitish. The basidia (33.3 to $40 \mu \mathrm{m}$ in length and $9-10 \mu \mathrm{m}$ in width) are hyaline, clavate, tetrasporic with sterigmata of $4 \mu \mathrm{m}$ or bisporiques with sterigmata of $6.66 \mu \mathrm{m}$. The cheilocystidia (43.3 $\mu \mathrm{m}$ in length and $8.3 \mu \mathrm{m}$ in width) are hyaline, cylindrical with a rounded apex and thick wall. Basidiospores ( 8.3 to $10 \mu \mathrm{m}$ in length and 6.6 to 8.3 $\mu \mathrm{m}$ in width) are globose, angular and more or less thick wall.

\section{DISCUSSION AND CONCLUSION}

In Morocco, Malençon and Bertault, (1970) studied five genera (Rhodophyllus Quél., (1886), Claudopus Gillet, (1876), Eccilia (Fr.) P. Kumm., (1871), Nolanea (Fr.) P. Kumm., (1871), Entoloma P. Kumm., (1871) and Leptonia (Fr.) P. Kumm., (1871)) belongs to the Rhodophylloideae family (Entolomataceae). These two mycologists have encountered eight species belonging to the genus Entoloma, three of them have been described (Entoloma lividoalbum (Kühner \& Romagn.) Kubička, (1975), E. politum (Pers.) Donk, (1979) and E. sericeum Quél., (1872)) and five species (Entoloma clypeatum (L.) P. Kumm., (1871), E. lividum Quél., (1872), E. nidorosum (Fr.) Quél., (1872), E. prunuloides (Fr.) Quél., (1872 ) and E. rhodopolium (Fr.) P. Kumm., (1871)) 
reported in different regions of Morocco (Tangier, the Rif, Central Plateau, Forest of Mamora, coastal Meseta, Middle Atlas, High Atlas). These species are also cited in other bibliographic works (El Kholfy et al., (2011); Laouz et al., (2012) and Haimed et al., (2013)).

Other works in Morocco concerned the species of this genus. El-Asfouri (2006) studied four species: Entoloma clypeatum (L.) P. Kumm., (1871), E. rhodopolium (Fr.) P. Kumm., (1871), E. sericeum Quél., (1872) and E. hirtipes (Schumach.) M.M. Moser, (1978) in the Mamora forest. Larouz, (2007) reported three species in the Middle Atlas: Entoloma nitens (Velen.) Noordel., (1979), E. lividoalbum (Kühner \& Romagn.) Kubička, (1975) and $E$. vernum S. Lundell, (1937). Haimed (2007) and Haimed et al., (2015) studied two species in the Moroccan central plateau (northeastern Morocco): Entoloma mougeotii (Fr.) Hesler, (1967) and E. rusticoides (Gillet) Noordel., (1981). Similarly, Outcoumit (2011) reported two species: Entoloma lividoalbum and E. undatum (Gillet) MM Moser, (1978) in the Tangier region. In this study, Entoloma papillatum, encountered in the forest of Mamora, is new to the Moroccan fungal flora.

The genera Nolanea was also studied in Morocco by Malençon and Bertault, (1970). These authors described six species (Nolanea africana Maire, (1928); $N$. clandestina (Fr.) P. Kumm., (1871), N. fusciceps (Kauffman) Largent, (1971), N. juncina (Kühner \& Romagn.) P.D. Orton, (1960), N. mammosum (L.) Hesler, (1967), N. proletaria (Fr.) Gillet, (1876)) and reported Nolanea staurospora Bres., (1881) in a marshy place near to Tangier We encountered for the first time Nolanea hirtipes (Schumach.) P. Kumm., (1871) and N. cucullata (J. Favre) P.D. Orton, (1960) in the forest of El Harcha and these two species can also be considered as new ones in Morocco.

\section{REFERENCES}

Bas C., 1969. Morphology and subdivision of Amanita and a monograph on its section Lepidella, Persoonia, 5 (4): 285-579.

Co-David D.L.V., Langeveld D., Noordeloos M.E., 2009. The molecular phylogeny and spore evolution of Entolomataceae. Persoonia, 23: 147-176.

Courtecuisse R. et Duhem B., 2000. Guide des champignons de France et d'Europe. Ed. Delachaux et Niestlé, S. A. Lausane (Switzerlande), Paris, 476p.

Dennis R.W.G., 1953. Les Agaricales de l'Ile de la Trinité. Rhodosporae-Ochrosporae. Bulletin de la Société Mycologique de France, 69: 145-198.

Dennis R.W.G., 1970. Fungus flora of Venezuela and adjacent countries. Kew Bulletin Additional Series, 3: 1531.
El-Assfouri A., 2006. Biodiversité fongique du Maroc: Inventaire et étude des Basidiomycètes de la forêt de la Mamora. Thèse de Doctorat, Université Ibn Tofail, Faculté des Sciences de Kénitra, Maroc, 301p.

El kholfy S, Aït Aguil F, Ouazzani Touhami A, Benkirane A \& Douira A 2011. Bibliographic Inventory of Moroccan Rif's fungi: Catalog of rifain fungal flora, Journal of Animal \& Plant Sciences, 12(1): 1493-1526.

Fries E.M., 1821. Systema Mycologicum, Fungorum, Vol 1, Lundae.

Gates G.M., Noordeloos M.E., 2007. Preliminary studies in the genus Entoloma in Tasmania - I. Persoonia, 19: 157-226.

Haimed M., Nmichi A., Ouazzani Touhami A., Benkirane R. \& Douira A., 2013. Bibliographic inventory of Moroccan Central Plateau fungi. Journal of Animal \&Plant Sciences, 18 (2): 2723-2749

Haimed M., El Kholfy S., El-Assfouri A., Ouazzani Touhami A., Benkirane R. \& Douira A., 2015. Inventory of Basidiomycetes and Ascomycetes harvested in the Moroccan Central Plateau. Int. J. Pure App. Biosci., 3 (1): 100-108.

Henkel T., Catherine Aime M., Largent D.L. et Baroni T.J., 2014. The Entolomataceae of the Pakaraima Mountains of Guyana 6: ten new species and a new combination in Nolanea. Mycotaxon, 129(1): 119-148.

Horak E., 1980. Entoloma (Agaricales) in Indomalaya and Australasia. Beihefte Nova Hedwigia, 65:1-352.

Horak E., 2008. Agaricales of New Zealand 1: Pluteaceae - Entolomataceae. The fungi of New Zealand vol. 5. Fungal Diversity Press, Hong Kong.

Kirk P.M., Cannon P.F., Minter D.W., Stalpers J.A., 2008. Dictionary of the Fungi. 10th edn. CABI, Wallingford, UK.

Largent D.L., 1994. Entolomatoid fungi of the Pacific Northwest and Alaska. Mad River Press, USA.

Largent D.L., Baroni T.J., 1988. How to identify mushrooms to genus VI: modern genera. Eureka, Mad River Press Inc., 277 p.

Larouz B., 2007. Biodiversité fongique du Maroc : Etude des champignons supérieur du Moyen Atlas. Thèse de Doctorat, Université Ibn Tofaïl, Faculté des Sciences, Kénitra, Maroc, 322 p.

Malençon G. et Bertault R., 1970. Flore des champignons supérieurs du Maroc, Tome I. Faculté des Sciences de Rabat, Maroc, 601 p.

Manimohan P., Noordeloos M.E., Dhanya A.M., 2006. Studies on the genus Entoloma (Basidiomycetes, Agaricales) in Kerala State, India. Persoonia, 19: 45-94.

Noordeloos M.E., 1981. Introduction to the taxonomy of the genus Entoloma sensu lato (Agaricales). Persoonia, 11: $121-151$. 
Noordeloos M.E., 1992. Entoloma s.l. Fungi Europaei, vol. 5. Giovanna Biella, Italy, 759 p.

Noordeloos M.E., 2004. Entoloma s.l. Fungi Europaei, vol. 5a. Edizione Candusso, Italy.

Noordeloos M.E., Hausknecht A., 2007. The genus Entoloma (Basidiomycetes, Agaricales) of the Mascarenes and Seychelles. Fungal Diversity, 27: 111-144.

Noordeloos M.E., Gates G.M., 2009. Preliminary studies in the genus Entoloma in Tasmania II. Cryptogamie, Mycologie, 30: 107-140.

Nounsi A., Outcoumit A., Selmaoui K., Ouazzani Touhami A., Benkirane R. \& Douira A., 2014. Inventaire des champignons ectomycorhiziens du Maroc. Journal of Applied Biosciences, 79:6826 - 6854.

Outcoumit A., 2011. Contribution à l'étude de la diversité fongique du Maroc et mise en évidence de quelques espèces fongicoles et de l'importance des espèces sécotoïdes dans la systématique des Basidiomycètes. Thèse de Doctorat, Université Ibn Tofaïl, Faculté des Sciences, Kénitra, Maroc. Volume I et II, 497p.
Pegler D.N., 1983. Agaric flora of the Lesser Antilles. Kew Bulletin Additional Series, 9: 1-668.

Pegler D.N., 1997. The agarics of São Paulo, Brazil. London, Royal Botanic Garden Kew, 68 p.

Perraudin N., 2002. Etude cartographique et inventaire patrimonial des entolomes de lorraine en l'état actuel des connaissances. Thèse de Doctorat, Faculté de Pharmacie, Universite Henri Poincare, Nancy 1, France, 94p.

Roger P., 1981. Les champignons. Edition du Club Français Loisirs, Paris, avec l'autorisation des Editions Solar, 288p.

Romagnesi H., 1995. Atlas des champignons d'Europe, Bordas, Paris, 290 p.

Romagnesi H., Gilles G., 1979. Les Rhodophylles des forêts côtières du Gabon et de la Côte d'Ivoire avec une introduction générale sur la taxonomie du genre. Beihe• e zur Nova Hedwigia, 59: 1-649.

Roux P., 2006. Mille et un champignons. Éd. Roux: Sainte-Sigolène, France), 1223 p.
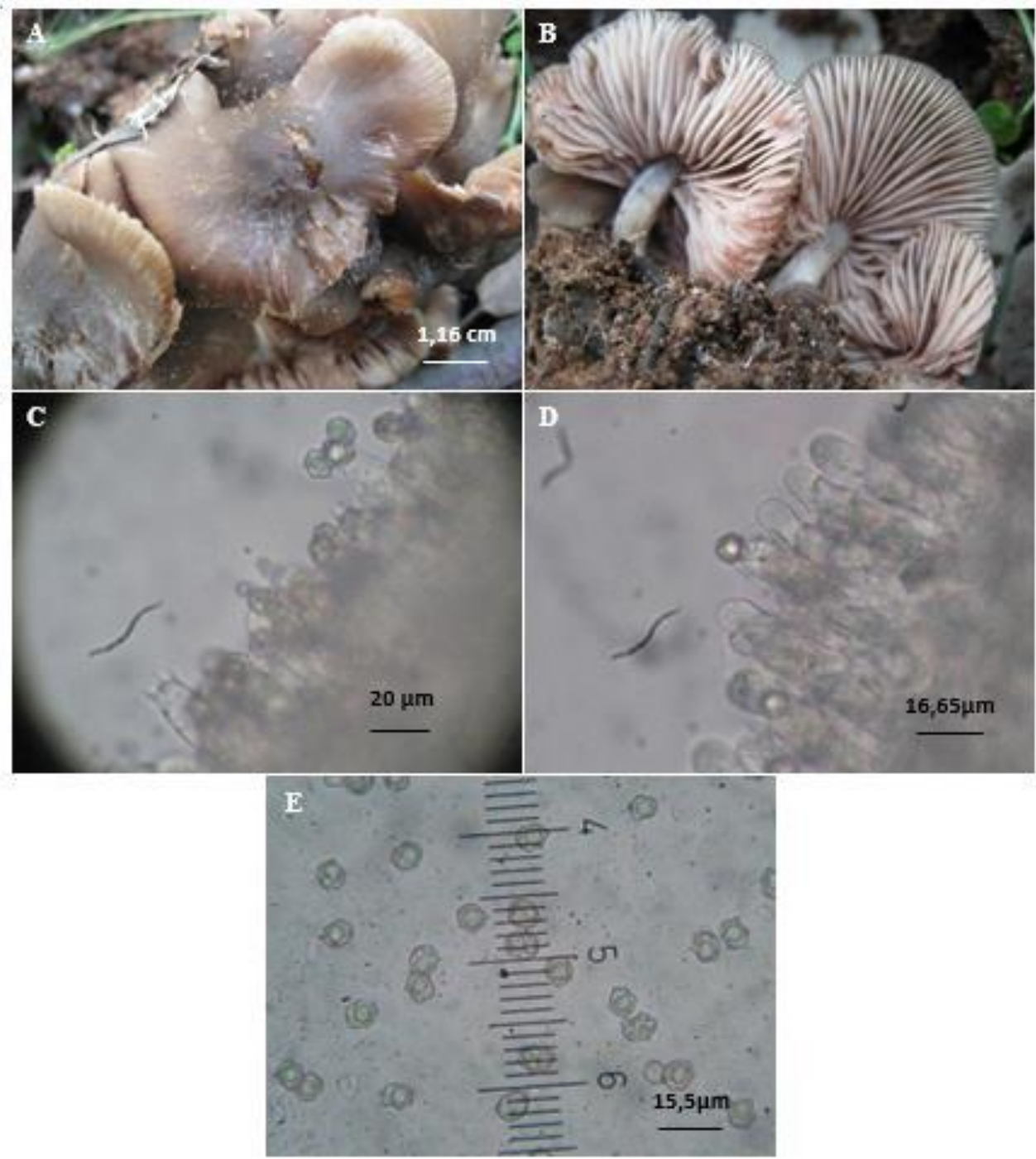

Figure: Cap surface (A), insertion of the blades $(B)$, basidia $(C)$, pleurocystidia $(D)$ and basidiospores $(E)$ of Entoloma papillatum $(\times 400)$. 


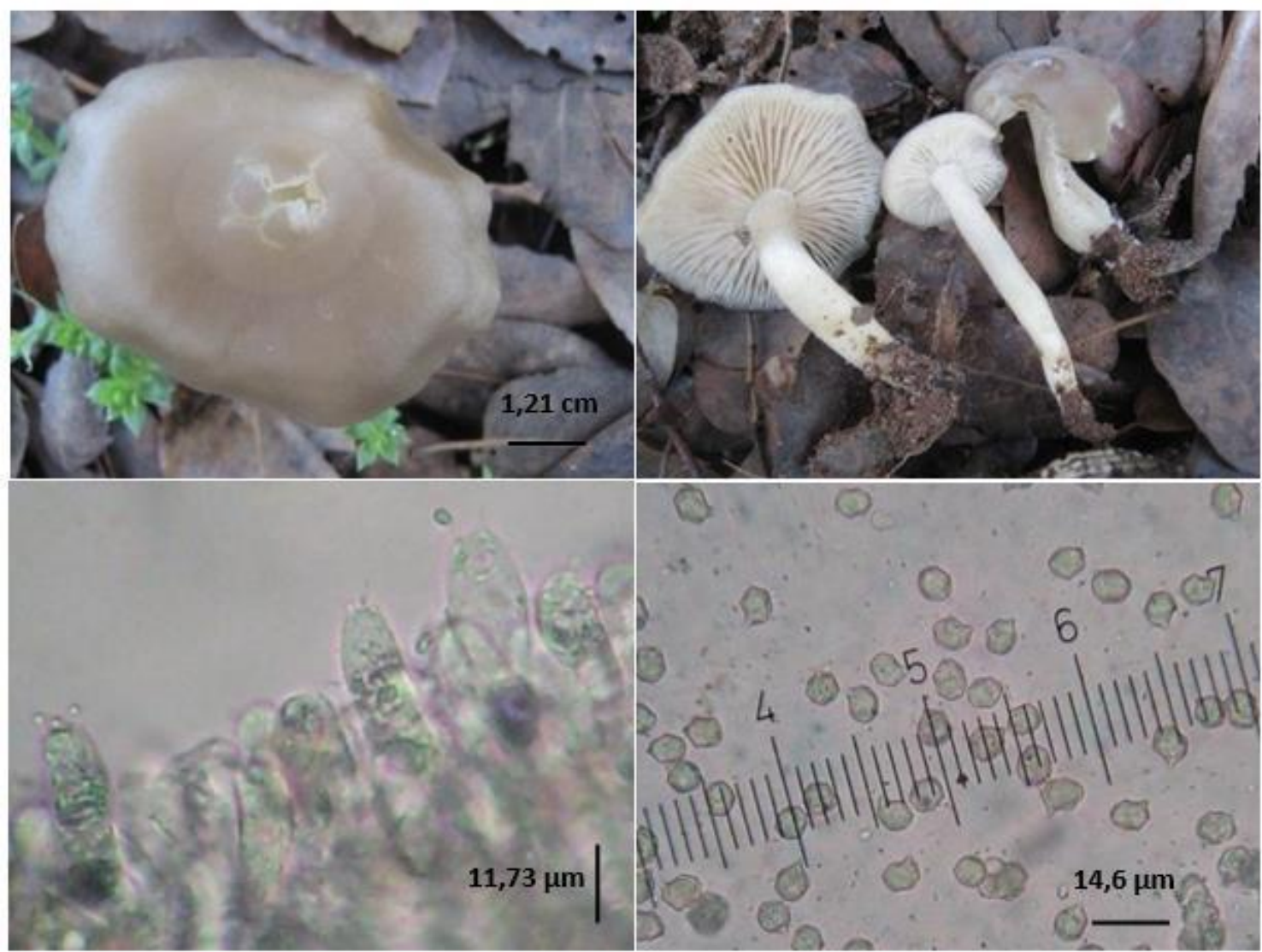

Figure: Cap surface (A), stipe and insertion of the blades $(B)$, basidia $(C)$ and basidiospores $(D)$ of Entoloma rhodopolium $(\times 400)$.

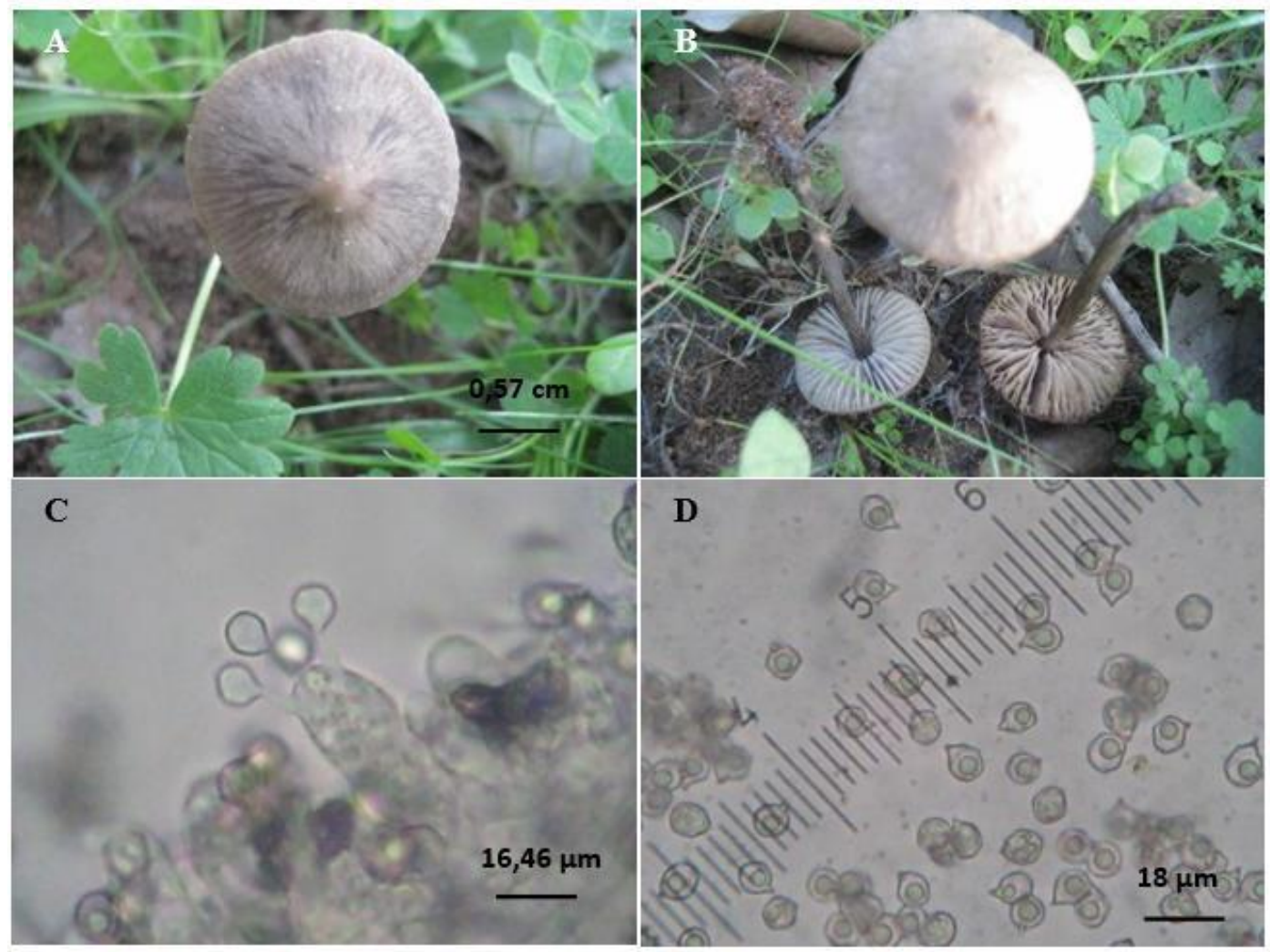

Figure1: Cap surface (A), stipe and insertion of blades (D), basidia (E) and basidiospores (F) of Nolanea hirtipes_( $\times 400)$. 

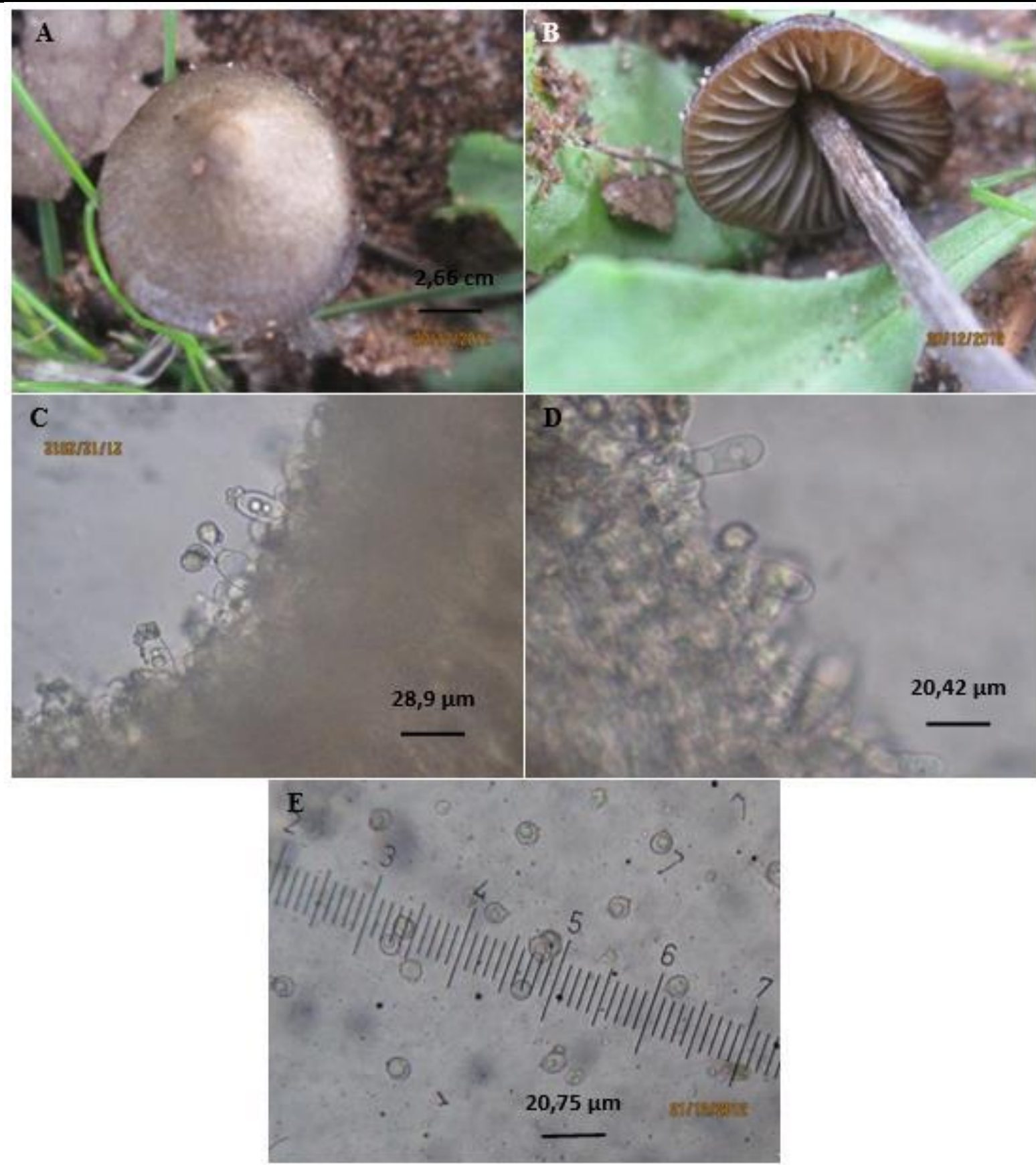

Figure: Cap surface (A), insertion of blades $(B)$, basidia $(C)$, cheilocystidia $(D)$ and basidiospores $(E)$ of Nolanea cucullata $(\times 400)$. 